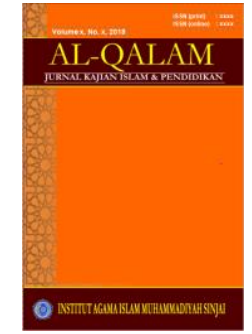

AL-QALAM

Jurnal Kajian Islam \& Pendidikan

Volume 11, No. 1, 2019

ISSN (print) : 1858-4152

ISSN (online) : 2715-5684

Homepage : http://journal.iaimsinjai.ac.id/index.php/al-qalam

\title{
KEPEMIMPINAN PENDIDIKAN ISLAM
}

\author{
Dr. H. Burhanuddin, M. A ${ }^{\mathbf{1}}$, \\ ${ }^{1}$ Institut Agama Islam Muhammadiyah Sinjai, Jln Sultan Hasanuddin No. 20, Sinjai, Sulawesi Selatan \\ burhanuddiniaimsinjai@gmail.com,
}

\begin{abstract}
Abstrak
Kepemimpinan adalah suatu kegiatan dalam membimbing suatu kelompok sehingga tercapai tujuan dari kelompok itu, yaitu tujuan bersama. Kepemimpinan adalah kemampuan dan kesiapan yang dimiliki seseorang untuk dapat mempengaruhi, mendorong, mengajak, menuntun, menggerakkan orang lain agar ia menerima pengaruh itu. Secara garis besar tugas dan fungsi Kepala Sekolah adalah sebagai berikut: 1. Sebagai pendidik (educator). 2. Sebagai manager. 3. Sebagai administrator. 4. Sebagai supervisor. 5. Sebagai pemimpin (Leader). 6. Sebagai inovator.
\end{abstract}

Kata Kunci : Kepemimpinan, Pendidikan Islam

\section{Pendahuluan}

Kepemimpinan adalah suatu kegiatan dalam membimbing suatu kelompok sehingga tercapai tujuan dari kelompok itu, yaitu tujuan bersama, Kepemimpinan adalah kemampuan dan kesiapan yang dimiliki seseorang untuk dapat mempengaruhi, mendorong, mengajak, menuntun menggerakkan orang lain agar ia menerima pengaruh itu (Soetopo, 1982: 1). Kepemimpinan harus ada jika suatu organisasi hendak berjalan efektif. Oleh karena itu kepemimpinan dalam organisasi adalah kepemimpinan administratif atau kepemimpinan managerial. Karena pemimpin dalam organisasi merupakan manager yang menjalankan fungsi-fungsi menegemen sejak dari perencanaan (Planning), pengorganisasian (organizing), penggerakan (actuating) dan pengawasan (controling), dalam rangka mencapai tujuan organisasi secara efektif dan efesien.

Kepemimpinan dalam organisasi disebut juga kepemimpinan kependudukan (Status Leadership), dan kepemimpinan yang ada pada diri individu tanpa ada jabatan disebut kepemimpinan personal (kepemimpinan pribadi).Kouzer dan Posner menjelaskan " Leadership is relationship, one between constituent and leader what base on mutual needs and interest (Posner, 1993: 11). Pendapat ini menekankan bahwa kepemimpinan itu kondisi dari adanya pemimpin (anggota) dan situasi saling memerlukan satu sama lain.

Dalam bahasa Arab, kepemimpinan sering diterjemahkan sebagai al-Ri'ayah, al-imarah, alqiyadah, atau al- zaamah.Kata-kata tersebut memiliki satu makna sehingga disebut sinonim atau murodif, sehingga kita bisa menggunakan salah satu dari keempat kata tersebut untuk menerjemahkan kata kepemimpinan.Sementara itu, untuk menyebut istilah kepemimpinan pendidikan, para ahli lebih memilih istilah qiyadah tarbawiyah.

Dalam Islam, kepemimpinan begitu penting sehingga mendapat perhatian yang sangat besar. Begitu pentingnya kepemimpinan, mengharuskan perkumpulan untuk memiliki pimpinan, bahkan perkumpulan dalam jumlah yang kecil sekalipun Nabi Muhammadi saw., bersabda:Dari Abu Said dari Abu Hurairah bahwa keduanya berkata, Rasulullah saw., bersabda, "Apabila tiga orang keluar bepergian, hendaklah mereka menjadikan salah satu sebagai pemimpin" (Hadits riwayat Abu Daud ) (Qamar, 2007: 268-269). dahulu.

Untuk memberikan pengerttian pendidikan, lebih baik kalau melihat konsep pendidikan terlebih 


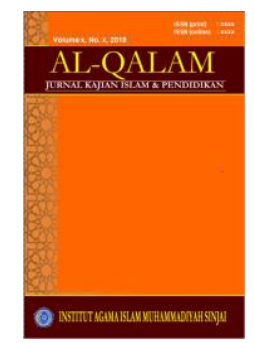

AL-QALAM

Jurnal Kajian Islam \& Pendidikan

Volume 11, No. 1, 2019

ISSN (print) : 1858-4152

ISSN (online) : 2715-5684

Homepage : http://journal.iaimsinjai.ac.id/index.php/al-qalam

Menurut Ki Hajar Dewantoro, mendidik adalah menuntun segala kekuatan yang ada pada anakanaknya mereka sebagai manusia dan anggota masyarakat sehingga mencapai keselamatan dan kebahagiaan yang setinggi-tingginya (Abu Daud, : 125).

Sedangkan menurut Ahmad. D. Marimba adalah bimbingan atau pimpinan secara sadar oleh pendidik terhadap terdidik menuju terbentuknya kepribadian yang utama (Abu Daud, : 125).

Dari pengertian tersebut diatas, dapat diambil kesimpulan bahwa pendidikan itu dilaksanakan oleh orang dewasa yang ditujukan kepada anak yang merupakan benih yang berkembang membutuhkan bimbingan dan bantuan.Pendidikan merupakan suatu hal yang penting bagi anak yang akan mengemban tugas, melaksanakan dan melanjutkan kekhalifahan dibumi yang mempunyai tanggung jawab di hadapan Allah swt.

\section{Metode}

Berisi jenis penelitian, waktu dan tempat penelitian, target/sasaran, subjek penelitian, prosedur, instrumen dan teknik analisis data serta hal-hal lain yang berkait dengan cara penelitiannya. target/sasaran, subjek penelitian, prosedur, data dan instrumen, dan teknik pengumpulan data, serta teknik analisis data serta hal-hal lain yang berkait dengan cara penelitiannya dapat ditulis dalam subsubbab, dengan sub-subheading. Sub-subjudul tidak perlu diberi notasi, namun ditulis dengan huruf kecil berawalkan huruf kapital, TNR-11 unbold, rata kiri.

Khususnya untuk penelitian kualitatif, waktu dan tempat penelitian perlu dituliskan secara jelas (untuk penelitian kuantitatif, juga perlu). Target/subjek penelitian (untuk penelitian kualitatif) atau populasi-sampel (untuk penelitian kuantitatif) perlu diurai dengan jelas dalam bagian ini. Perlu juga dituliskan teknik memperoleh subjek (penelitian kualitatif) dan atau teknik samplingnya (penelitian kuantitatif).

\subsection{Addsd}

Prosedur perlu dijabarkan menurut tipe penelitiannya. Bagaimana penelitian dilakukan dan data akan diperoleh, perlu diuraikan dalam bagian ini. Untuk penelitian eksperimental, jenis rancangan (experimental design) yang digunakan sebaiknya dituliskan di bagian ini. Macam data, bagaimana data dikumpulkan, dengan instrumen yang mana data dikumpulkan, dan bagaimana teknis pengumpulannya, perlu diuraikan secara jelas dalam bagian ini.

\subsection{Xss}

Bagaimana memaknakan data yang diperoleh, kaitannya dengan permasalahan dan tujuan penelitian, perlu dijabarkan dangan jelas. Catatan: Sub-subbab bisa berbeda, menurut jenis atau pendekatan penelitian yang digunakan. Jika ada prosedur atau langkah yang sifatnya sekuensial, jika subbab bukan merupakan judul maka hanya menggunakan huruf. Misalnya sebagai berikut:
a. Poin Satu
b. Poin dua
c. Poin tiga
d. Dan seterusnya.

\section{Hasil dan Pembahasan}

\subsection{Kepemimpinan dan Manajemen}

Kepemimpinan adalah proses mempengaruhi atau memberi contoh oleh pemimpin kepada yang dipimpinnya (pengikutnya) dalam upaya mencapai tujuan organisasi.Kebanyakan orang masih cenderung mengatakan bahwa pemimpin yang efektif mempunyai sifat atau ciri-ciri tertentu yang sangat penting misalnya; kharisma, pandangan kedepan, daya persuasu, dan intersitas. Dan memang, apabila kita berpikir tentang pemimpin yang heroik seperti Napoleon, Washington, 


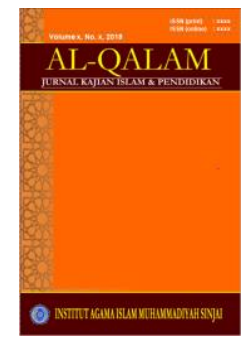

AL-QALAM

Jumal Kajian Islam \& Pendidikan

Volume 11, No. 1, 2019

ISSN (print) : 1858-4152

ISSN (online) : 2715-5684

Homepage : http://journal.iaimsinjai.ac.id/index.php/al-qalam

Lincoln, Cgurcill, Sukarno, Jenderal Sudirman, dan sebagainya. Kita harus mengetahui bahwa sifat-sifat seperti melekat pada diri mereka dan manfaatkan telah untuk mencapai tujuan yang mereka inginkan.

Berikut berbagai defenisi yang ada, maka dapat dikatakan bahwa kepemimpinan adalah:

a) Seni untuk mencapai kesesuaian paham.

b) Bentuk persuasi dan inspirasi.

c) Kepribadian yang mempunyai mengaruh.

d) Tindakan dan perilaku.

e) Titik sentral proses kegiatan kelompok.

f) Hubungan kekuatan/ kekuasaan.

g) Sarana pencapaian tujuan

h) Hasil dari interaksi

i) Peranan yang dipolakan

j) Inisiasi struktur.

Pengertian Managemen, Kata manajemen berasal dari bahasa Prancis Kuno menagement, yang memiliki arti "Seni melaksanakan dan mengatur".Managemen belum memiliki definisi yang mapan dan diterima secara universal.

Mary Parker Follet, misalnya mendefinisikan manajemen sebagai seni menyelesaikan pekerjaan melalui orang lain. Definisi ini berarti “ bahwa seorang manajer bertugas mengantar dan mengarahkan orang lain untuk mencapai tujuan organisasi. Ricky W. Grittin mendefinisikan managemen sebagai sebuah proses perencanaan, pengorganisasian, pengkoardinasian dan pengontrolan sumber daya untuk mencapai sasaran secara efektif dan efisien. Efektif berarti bahwa tujuan dapat dicapai sesuai dengan perencanaan, sementara efisienn berarti bahwa tugas yang ada dilaksanakan secara benar, terorganisasi, dan situasi dengan jadwal. Diantara tugas manajerial seorang guru yaitu:

\subsection{Pengelolaan Administrasi Guru Peserta Didik}

Pengelolaan administrasi guru dan peserta didik dilakukan oleh: (1) Guru berkewajiban mengisi daftar hadir peserta didik dan guru, (2) Guru membuat catatan-catatan tentang kejadiankejadian di kelas berdasarkan format yang disediakan, (3) Guru mengisi laporan kemajuan belajar peserta didik, absensi peserta didik, keterlambatan peserta didik dan membuat rekapan sesuai format yang disediakan, (4) Guru membuat laporan terhadap hal-hal khusus yang memerlukan penanganan kepada penanggung jawab akademik, (5) Guru membuat jadwal topik/materi yang dianjurkan kepada peserta didik.

a) Provil dan Persyaratan Guru yang Professional

Professi guru masih dihadapkan kepada banyak permasalahan, karena professi guru merupakan suatu professi yang sedang tumbuh, semua permasalahannya harus relevan untuk dibicarakan, salah satu diantaranya profesi harus melalui pendidikan tinggi keguruan. Hal ini sejalan dengan UU No. 14 Tahun 2005 pasal 8 menyatakan guru wajib memiliki kwalifikasi akademik, kompetensi, sertifikasi pendidik, sehat jasmani dan rohani semiliki, kemampuan untuk mewujudkan tujuan pendidikan nasional. Kemudian pasal 9 manyatakan kwalifikasi akademik sebagaimana yang dimaksud dengan pasal 8 diperoleh melalui pendidikan tinggi program serjana atau program diploma empat. Pembahasan pada bagian ini mengenai standar yang 


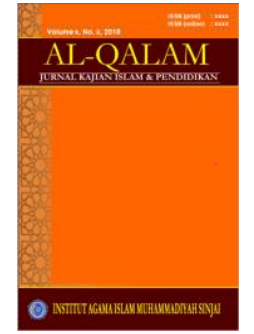

AL-QALAM

Jurnal Kajian Islam \& Pendidikan

Volume 11, No. 1, 2019

ISSN (print) : $\underline{1858-4152}$

ISSN (online) : 2715-5684

Homepage : http://journal.iaimsinjai.ac.id/index.php/al-qalam

dipersyaratkan menjadi guru yang professional meliputi tugas dan tanggung jawab guru, guru professional senantiasa meningkatkan kualitasnya, standar profesional guru di Indonesia, dan kode etik dan kepribadian guru.

b) Mempunyai Kompetensi Pedagogik, Kepribadian, Profesional, dan Sosial

Kompetensi pedagogik terkait dengan kesungguhan dalam mempersiapkan pelajaran, keteraturan dan ketertiban dalam menyelenggarakan pembelajaran, kemampuan mengelola kelas, kedisiplinan dan kepatuhan terhadap akademik, kemampuan melaksanakan penilaian prestasi belajar peserta didik, objektivitas dalam penilaian terhadap peserta didik.

Kompetensi profesional menjadi penguasaan bidang keahlian yang menjadi tugas pokoknya, kemampuan menunjukkan keterkaitan antara bidang keahlian yang diajarkan, keterkaitan antara bidang keahlian yang diajarkan, kesediaan melaksanakan refleksi dan diskusi (sharing) permasalahan pembelajaran yang dihadapi.

Selanjutnya kompetensi kepribadian meliputi kewibawaan sebagai peribadi pendidik, kearifan dalam mengambil keputusan, menjadi contoh dalam bersikap dan berperilaku, satunya kata dan perbuatan, kemampuan mengendalikan diri salam berbagai situasi dan kondisi serta adil dalam memperlakukan teman sejawat.

Adapun kompetensi sosial mennjadi kemampuan menyampaikan pendapat, kemampuan menerima kritik, saran dan pendapat orang lain, mudah bergaul dalam kalangan sejawat, karyawan dan peserta didik, serta toleran terhadap keragaman (plurakisme) di masyarakat.

Adapun kompetensi profesional diperoleh melalui pendidikan profesi keguruan yang dalam pelaksanaannya diatur dalam peraturan pemerintah RI No. 74 tahun 2007.Seorang pendidik profesional dalam berbagai kompetensi sebagaimana tersebut, harus terus dikembangkan dan diberdayakan diri yang dilakukan secara demokratis, berkeadilan, tidak diskriminatif, dan berkelanjutan dengan menjunjung hak-hak asasi manusia, nilai keagamaan, nilai kultural, kemajemukan bangsa dan kode etik profesi.

c) Manajemen Pendidikan Islam

Dari beberapa uraian manjemen dan pendidikan Islam ternyata adalah penggabungan dua ilmu yaitu manajemen dan pendidikan Islam. Menurut Prof. Dr. Mujamil Qomar manajemen pendidikan Islam adalah suatu proses pengelolaan lembaga pendidikan Islam secara damai dengan cara menyiasati sumber-sumber belajar dan hal-hal lain yang terkait untuk mencapai tujuan pendidikan Islam secara efektif dan efisien (Qomar, 2008: 10).

Lebih lanjut definisi diatas dapat dijabarkan untuk mempermudah pemahaman dan implikasi yang ada yaitu:

Pertama $=$ Proses pengelolaan lembaga pendidikan secara Islami. Dalam proses pengelolaan, aspek yang ditekankan adalah nilai keislaman yang bersumber pada alQur'an dan al-Hadits. Misalnya terkait dengan pemberdayaan, penghargaan, kualitas dan lain-lain. 


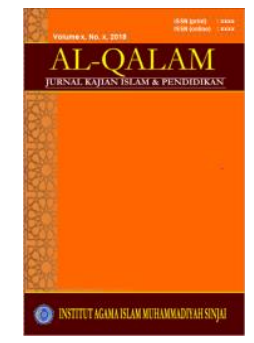

AL-QALAM

Jurnal Kajian Islam \& Pendidikan

Volume 11, No. 1, 2019

ISSN (print) : $\underline{1858-4152}$

ISSN (online) : 2715-5684

Homepage : http://journal.iaimsinjai.ac.id/index.php/al-qalam

Kedua $=$ Lembaga pendidikan Islam, fokus manajemen pendidikan Islam adalah menangani lembaga pendidikan Islam, mulai dari pesantren, Madrasah, Perhuruan Tinggi dan sebagainya.

Ketiga $=$ Proses pengelolaan pendidikan Islam secara Islami. Proses pengelolaan harus sesuai dengan kaidah-kaidah Islam atau memakai atau memakai kaidah-kaidah manajerial yang sifatnya umum tapi masih sesuai dengan nilai-nilai keislaman.

Keempat= Dengan cara menyiasati, Hal ini mengandung makna strategi, karena manjemen penuh siasat atau strategi yang diarahkan untuk mencapai tujuan. Demikian pula dengan manajemen pendidikan Islam yang selalu memakai strategi tertentu.

Kelima $=$ Sumber-sumber belajar dan hal-hal yang terkait, sumber-sumber belajar disini memiliki cakupan yang luas yaitu;

$>$ Manusia, yang meliputi guru, murid, pegawai dan pengawas

$>$ Bahan, yang meliputi buku, perpustakaan, dll

$>$ Lingkungan, merupakan segala hal yang mengarah ke masyarakat

$>$ Alat dan peralatan seperti alat peraga, laboratorium, dsb

$>$ Aktivitas, yang meliputi keadaan sosial politik, sosio kultural dalam masyarakat

Keenam = Tujuan pendidikan Islam, Tujuan merupakan hal yang vital yang mengendalikan dan mempengaruhi komponen-komponen dalam lembaga pendidikan Islam.

Ketujuh= Efektif dan efisien, Artinya, manjemen yang berhasil mencapai tujuan dengan penghematan tenaga, waktu dan biaya.

\subsection{Peran dan FungsinKepala Madrasah Sebagai Pemimpin Pendidikan}

Pekerjaan pemimpin pendidikan ialah menstimulir dan membimbing pertumbuhan guruguru secara kontinyu sehingga mampu melaksanakan dengan lebih baik segenap tugas mengajaran sehingga akhirnya mampu menstimulir dan membimbing murid-murid untuk dapat berpartisipasi didalam masyarakat. Kepala madrasah harus mampu menciptakan situasi belajar yang baik. Berarti bahwa ia harus mampu mengelolah "School Plant", pelayanan-pelayanan khusus sekolah, dan fasilitas-fasilitas pendidikan sehingga guru-guru dan murid-murid memperoleh kepuasan menikmati kondisi-kondisi karya, mengelola personalia pengajaran dan murid, membina kurikulum yang memenuhi kebutuhan anak, dan mengelola catatan-catatan pendidikan.

Sebagai pemimpin pendidikan, Kepala Madrasah bertanggung jawab untuk pertumbuhan guru-guru secara kontinyu. Dengan praktek demokratis, ia harus mampu membantu guru mengenal kebutuhan masyarakat sehingga tujuan pendidikan memenuhi hal itu.

Besar kecilnya peranan yang dilakukan seorang pemimpin banyak ditentukan kepada siapa, dan apa yang dipimpinnya. Kekuasaan (otoritas) apa yang dimiliki dan wawasan/ peringkat mana ia berperan sebagai pemimpin, baik itu pemimpin formal maupun non formal, tetapi kesemuanya berperan dalam membimbing, menuntun, mendorong, dan memberikan motivasi kepada mereka yang dipimpinnya. Fungsi utama kepala madrasah (sekolah) sebagai pemimpin pendidikan ialah menciptakan situasi belajar dan mengajar yang baik sehingga para guru dan para siswa dapat mengajar dan belajar dalam situasi yang baik.

Untuk melaksanakan fungsi tersebut, kepala madrasah memiliki tanggung jawab ganda yaitu melaksanakan administrasi sekolah sehingga tercipta situasi belajar mengajar yang baik, dan 


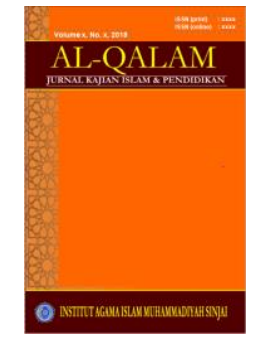

AL-QALAM

Jumal Kajian Islam \& Pendidikan

Volume 11, No. 1, 2019

ISSN (print) : 1858-4152

ISSN (online) : 2715-5684

Homepage : http://journal.iaimsinjai.ac.id/index.php/al-qalam

melaksanakan supervise sehingga guru tambah semangat dalam menjalankan tugas-tugas mengajarnya.

\section{Simpulan}

Kepemimpinan adalah suatau kegiatan dalam membimbing suatu kelompok sehingga tercapai tujuan dari kelompok itu, yaitu tujuan bersama. Kepemimpinan adalah kemampuan dan kesiapan yang dimiliki seseorang untuk dapat mempengaruhi, mendorong, mengajak, menuntun, menggerakkan orang lain agar ia menerima pengaruh itu. Secara garis besar tugas dan fungsi kepala madrasah / sekolah dapat disebutkan sebagai berikut:

a) Sebagai pendidik (educator)

b) Sebagai manajer

c) Sebagai administrator

d) Sebagai supervisor

e) Sebagai pemimpin (leadership)

f) Sebagai innovator

Kepemimpinan adalah suatu kegiatan dalam membimbing suatu kelopok sedemikian rupa sehingga tercapailah tujuan kelompok dimana tujuan tersebut merupakan tujuan bersama.

\section{Ucapan Terimakasih}

Bagian ini sifatnya pilihan, boleh tidak ada (optional). Ucapan terima kasih biasanya diberikan karena bantuan penulisan yang dipandang berpengaruh besar atau pun bantuan dana untuk melakukan penelitian.

\section{Daftar Pustaka}

Abu Daud Sulaiman Ibnu al-Asy’ats al-Sajistami, Sunan Abi Daud, (Indonesia: Maktabah Dahlan, $\mathrm{tt}$ )

Gattar, MS, Dasar-dasar Administrasi dan Supervisi Pendidikan (Jakarta: Angkasa Raya, 1992)

Hendiyat Soetopo, Wasty Soemanto, Kepemimpinan dan Supervisi Pendidikan, (Malang: Bima Aksara, 1984)

Idris, Zahara, Dasar-dasar Kependidikan, (Padang: Aksara Raya, 1981)

Kouzes J. M and Posner, B. 2, Credibility (San Prancaisco Yossey Bass Publishers, 1993)

Mujamil Qomar, Managemen Pendidikan Islam, (Jakarta: Glora Aksara Pratama, 2007)

Marno, Triyo Supriyatno, Manajemen dan Kepemimpinan Pendidikan Islam, (Bandung: Refika Aditama, 2008)

Marimba, Ahmad. D, Pengantar Filsafat Pendidikan, ( Bandung: Al- Ma'rif, 1989)

Purwanto, Ngalim, Administrasi dan Supervisi Pendidikan, (Bandung: Rosdakarya, 2006)

Rahma, et all, Peran Strategis Kepala Sekolah dalam Meningkatkan Mutu Pendidikan, (Jatinangor: Alqaprint, 2006) 